\title{
Exploring Heterogeneous Tourism Development Paths: Cascade Effect or Co-evolution in Niagara?
}

\section{Patrick Brouder \& Christopher Fullerton}

To cite this article: Patrick Brouder \& Christopher Fullerton (2015) Exploring Heterogeneous Tourism Development Paths: Cascade Effect or Co-evolution in Niagara?, Scandinavian Journal of Hospitality and Tourism, 15:1-2, 152-166, DOI: 10.1080/15022250.2015.1014182

To link to this article: https://doi.org/10.1080/15022250.2015.1014182

\section{Published online: 06 Mar 2015.}

\section{Submit your article to this journal $\longleftarrow$}

山 Article views: 387

Q View related articles $\asymp$

View Crossmark data \lceil

Citing articles: 13 View citing articles 주다. 


\title{
Exploring Heterogeneous Tourism Development Paths: Cascade Effect or Co-evolution in Niagara?
}

\author{
PATRICK BROUDER ${ }^{* * *, \dagger} \&$ CHRISTOPHER FULLERTON ${ }^{* *}$ \\ *Department of Tourism Studies \& Geography, Mid Sweden University, Sweden, **Department of \\ Geography, Brock University, Canada, and School of Tourism and Hospitality, University of \\ Johannesburg, South Africa
}

ABSTRACT Tourism is often galvanised around a central theme based on a region's strengths in product supply and promotional opportunity, which usually results in an identifiable regional brand. However, this also hides the existing heterogeneity of tourism supply, especially in regions with an established brand. Securing long-term community economic development requires a broader focus since some unheralded tourism development paths may prove resilient over the long term and ultimately contribute to community development. This paper investigates the less central stakeholders in the Niagara region of Canada and explores how future studies might integrate marginal tourism stakeholders in studies of the regional tourism economy. Through semi-structured interviews with regional tourism stakeholders, the analysis of the Niagara region, based on perspectives of co-evolution from evolutionary economic geography, reveals a new perspective on tourism development by focussing on the place of marginal stakeholders in a region with a strong tourism brand. The region exhibits strong path dependence based on its industrial and agricultural legacy but long-term, organic, incremental processes of change within the region are creating new tourism development paths. These new paths coevolve with the dominant tourism paths as well as other community development initiatives leading to positive change across the region.

KEY WORDS: community economic development, co-evolution, evolutionary economic geography, Niagara, path dependence, rural, tourism

\section{Introduction}

Tourism development has often occurred around a core product supply in a centralised destination which is packaged and promoted to the masses. Such an approach usually results in an identifiable regional brand which attracts tourists interested in the region's promoted offer. However, this also hides the heterogeneous nature of tourism supply in regions. In fact, tourism development occurs along many paths, not all of which are in 
line or on pace with the dominant regional brand. Some tourism research has focussed on the marginal actors in regional tourism economies (e.g. Karlsson, 2005; Milne \& Ateljevic, 2001; Papatheodorou, 2004), and this paper adds to this literature by investigating the less central tourism stakeholders in the Niagara region of Canada. We show why understanding the more marginal stakeholders in tourism regions is important if sustainable community development is to be achieved.

Niagara, like many iconic destinations, is often perceived in a homogeneous manner. Niagara Falls and the related tourist attractions draw millions of domestic and international visitors annually. Niagara is not, however, homogeneous in either regional development or tourism development. Economic restructuring has seen the region lose many thousands of manufacturing jobs over the last few decades, which, in turn, has prompted a growing reliance on tertiary sector employment, much of it in the tourism industry (Fullerton, 2013). Besides Niagara Falls, which has a strong emphasis on entertainment and gaming, the region has become well established as a leading New World wine region since the 1980s (Gayler, 2010). Much effort nowadays is put into supporting the image of a maturing wine region developing in tandem with complementary sectors, such as culinary tourism (Telfer \& Hashimoto, 2013).

Most tourism-related studies of the region have focussed on the mass tourism development in Niagara Falls (Dubinsky, 1999) and the development of the wine region (Carmichael, 2005; Ripmeester, Mackintosh, \& Fullerton, 2013; Telfer, 2001). However, the region's tourism supply is more diverse than a cursory glance shows; that is, tourism is not only the Falls, the entertainment district and a few large wineries. Despite this being the case, tourism development beyond that directly associated with the Falls and the wine industry is poorly understood. This represents a research gap that should be filled in order to facilitate sustainable long-term development since the less noticed development paths may prove robust over the long term and may ultimately contribute to community development in the broader Niagara region.

\section{Aim and Research Questions}

This paper contributes to tourism studies by highlighting the heterogeneous nature of tourism development and argues for a greater understanding of the often hidden voices of the marginal stakeholders within relatively successful regions. This is important because the laggards of today may be the leaders of tomorrow. The paper departs from the following broad view of Niagara tourism:

(1) corporations dominating the entertainment/gaming sector in urban Niagara Falls;

(2) capital-intensive SMEs dominating the wine sector in the surrounding region and

(3) Micro-enterprises engaged in nature-based/other tourism across the region.

This paper focusses on (3), which has received little attention. Tourism development is often understood using simple economic metrics, such as the number of jobs and the number of bed nights, but in more marginal communities it can also be measured through other positive community outcomes, such as enhanced quality of place and quality of life (cf. Brouder, 2012, 2013; Reijonen, 2008). Sub-sectors which do not perform as well as the dominant regional development path are often ignored since the impacts are likely to be subtle and difficult to measure. Thus, most studies focus 
on the greatest successes while ignoring more modest gains. The following research questions guide the empirical investigation:

(1) Which other tourism development paths (besides gaming/entertainment/wine) exist in the Niagara region? And how extensive are they vis-à-vis the more dominant paths?

(2) How do marginal tourism stakeholders perceive their position within regional branding, in particular, and destination development, in general?

(3) How much relational exchange (formal networks and informal interactions) exists between marginal stakeholders and more central ones?

(4) How much relational exchange exists (again, formal and informal) between the marginal stakeholders and the wider (non-tourism) group of community stakeholders?

(5) What is the development potential of these marginal paths over the long term?

\section{Background to the Study Area}

The Niagara region consists of 12 urban and rural municipalities (Figure 1). With just over 431,000 residents, Niagara's population increased by only 6.9 per cent between 1996 and 2011, one of the lowest growth rates in Southern Ontario. This is largely

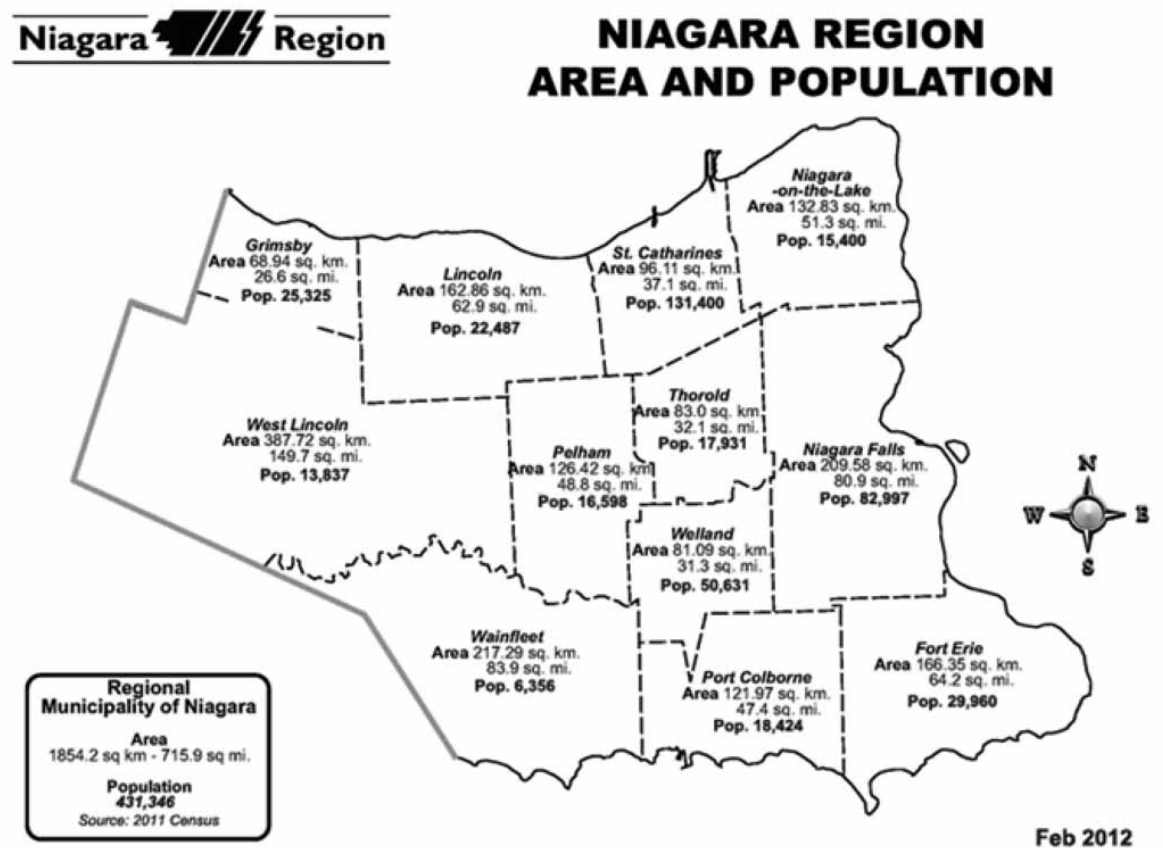

Figure 1. Communities of the Niagara Region (source: Niagara Region, 2012). 
due to the weak economic climate experienced locally in recent decades. Historically, manufacturing has been one of the region's three economic pillars, along with agriculture and tourism. Employment in this sector has dropped from 47,000 to just over 25,000 in recent decades (Hickey, 2008), with dozens of large firms relocating to the USA and various overseas locations where production costs are lower (Fullerton, 2013). Economic shocks have also been felt in the historically strong agricultural sector. Niagara is one of Canada's most important sources of grape and tender fruit crops but the value-added processing associated with this has largely ceased. For example, the Welch's grape juice plant and the CanGro cannery have both closed in the last decade, eliminating hundreds of jobs and leaving hundreds of Niagara farmers without a buyer for their produce (Eaton, 2004).

It has been amidst this fairly bleak economic landscape that the tourism development activities examined in this paper are occurring. Tourism has perhaps been the most resilient of the region's three traditional economic pillars, but it has also been struggling. Niagara's tourism industry has always centred on the iconic waterfalls on the Niagara River and the surrounding city of Niagara Falls. The flow of tourists to "the Falls" (as they are known colloquially) grew throughout the twentieth century, particularly after the rise of the automobile in the 1950s (Dubinsky, 1999). However, even the worldfamous Falls have not been immune to the cycles of the economy and the impacts of well-known geopolitical events, such as the 9/11 terrorist attacks (Jayawardena, Patterson, Choi, \& Brain, 2008). Efforts to bolster the local tourism economy led to an increase in the number of visitor attractions after the mid-1990s, most notably through the provincial government's opening of two casinos (in 1996 and 2004) (MacLaurin \& Wolstenholme, 2008). These initiatives have since prompted several transnational corporations to build hotels, restaurants and other tourism-related businesses in Niagara Falls. Despite these developments, visitation levels continue to stagnate (Brooker \& Burgess, 2008). It is estimated that Niagara currently attracts about 11 million tourists per year, down significantly from the 16 million who routinely visited in the years before 9/11 (Deloitte \& Touche, 2008).

The stagnation of Niagara Falls' tourism economy in the early 2000s prompted an intensive search for potential remedies (Jayawardena et al., 2008; Ontario Tourism Competitiveness Study, 2009). A recurring conclusion has been that municipalities throughout Niagara possess assets that might be used to diversify the region's tourism offering beyond only those in Niagara Falls and, with this, that there is great potential for tourism development to contribute to the region's economic revitalisation. Certainly, some diversification was already underway by the late 1990s in a few parts of Niagara, most notably in Niagara-on-the-Lake, which has worked vigorously to promote its cultural and built heritage (Mitchell, Atkinson, \& Clark, 2001). Furthermore, the growing reputation of Niagara wines through the early 2000s helped to cultivate a thriving wine tourism industry in Niagara-on-the-Lake and, successively, in other parts of the region situated below the Niagara Escarpment (Fullerton, 2013; Telfer \& Hashimoto, 2013). Today, municipalities throughout Niagara have embraced tourism as part of their economic development strategies. While in Niagara Falls the main concern is to bring visitor numbers back up to their former heights, many of the region's more rural communities are looking to grow their nascent tourism economies in order to compensate for agricultural and industrial decline. 
The tourism development activities of the rural Niagara municipalities have varied considerably, depending largely on the nature of their place-based assets. Those that are blessed with the right soil and climate conditions, such as Grimsby and Lincoln, have been able to latch on to Niagara's emerging wine industry, while those straddling the Lake Erie shoreline, such as Wainfleet, Port Colborne and Fort Erie, have focussed their efforts on growing their water-based tourism and recreation industries, such as sport fishing and second-home tourism. Others, such as Thorold and Pelham, have emphasised agri-tourism as a development strategy.

Despite the region-wide tourism development, there has been a lack of coordination in tourism marketing among the area's towns and cities, with the Niagara region having been identified in one provincial government report as being guilty of duplication of tourism promotion efforts (Ontario Tourism Competitiveness Study, 2009; cf. Jayawardena et al., 2008). In turn, both academic and consultant studies have asserted that there is a lack of a clear "Niagara" brand beyond the Falls, leading to an inconsistent and limited international image for Niagara (Deloitte \& Touche, 2008; Jayawardena et al., 2008). The Government of Ontario addressed this concern in 2010 through the creation of the Tourism Partnership of Niagara (TPN), whose mandate is "to provide leadership and coordination to attract more visitors, generate more economic activity and create more jobs across the Niagara region" (http://www.niagarasrto.com). The TPN is responsible for representing all 12 Niagara region municipalities in tourism marketing and is expected to work closely with the municipalities, tourism agencies and businesses. Whether this constellation leads to a more focussed brand or to a more contested tourism economy is the focus of this paper.

\section{Tourism and Sustainable Regional Development}

This paper explores tourism as part of sustainable regional development rather than as an end in itself (cf. Kauppila, Saarinen, \& Leinonen, 2009). Development is defined here in terms of community economic development (CED), which

actively incorporates the widespread involvement of community stakeholders in the planning and implementation of economic, social, cultural, and other projects aimed at improving local quality-of-life [and also] places a stronger (though not complete) emphasis on the procurement of local investment and the identification, training and continued activity of local entrepreneurial talent. (Fullerton, 2010, p. 427)

Thus, development is closely aligned with endogenous enterprise and is not necessarily growth-oriented. Tourism businesses are a resource for CED, and their activity is a requirement for long-term community survival.

In order to understand development, it is necessary to analyse the processes of change at the grass-roots level. This paper draws on evolutionary economic geography (EEG) in order to understand change in tourism (Brouder, 2014a; Brouder \& Eriksson, 2013a). EEG is an emerging field within economic geography and focuses on how past conditions both constrain and enable future courses of regional development (Boschma \& Martin, 2010). EEG incorporates heterodox thinking into local and regional development 
studies, opening up for "academic understanding of small-scale tourism in regions where it is not the dominant sector, or where it is made up of multiple (perhaps even contesting) paths" (Brouder, 2014b, p. 542). It is particularly appropriate for studies in rural regions where economic restructuring has created macro-trends of decline but where new paths are emerging and need to be explored at a highly localised level (cf. Brouder, 2014b).

One foundational concept informing EEG is path dependence - the long-term process by which reinforcement mechanisms in the regional economy help certain economic structures to prosper through, for example, economies of scale, while these same mechanisms may cause long-term problems of regional lock-in to a particular dominant path (cf. Martin, 2010). Many rural regions in the hinterland of metropolitan areas enjoyed tremendous economic advancement in the post-Second World War era. However, this path-dependent development has since led to devastation for many single-industry towns in rural regions as they tended to not be as diverse as their metropolitan counterparts. The resultant socio-economic landscape in regions, such as the Niagara region, has been described as industrial ruination (Mah, 2012). However, even in a "ruined" landscape, there are the seeds of structural change (cf. Neffke \& Svensson Henning, 2010) and these "seeds" are important research subjects.

Brouder and Eriksson (2013a) highlight the open nature of the economy in which tourism entrepreneurs operate, including the dynamic interaction with surrounding agents both inside and outside of the tourism sector. Thus, when the tourism economy is studied over the long term, co-evolutionary processes of development can be expected to occur. Co-evolution is a useful concept within EEG as it highlights the heterodox nature of the tourism economy within the regional economy (Brouder, 2014a), a fact often overlooked in empirical studies which still tend to unilineal explanatory models, an old critique in tourism studies (Cohen, 1979) but one which still resonates today. That the tourism economy is a complex system is axiomatic in tourism studies today (Milne \& Ateljevic, 2001) but co-evolution, in particular, has been scarcely explored empirically (e.g., Larsson \& Lindström, 2013). While Larsson and Lindström (2013) focussed on cross-sectoral co-evolution, it is also necessary to explore co-evolution within the tourism sector (cf. Ma \& Hassink, 2013).

Ruhanen (2013) argues that institutions (e.g. local governments) have a powerful role in sustainable tourism development but that role may be positive or negative as local government can inhibit just as easily as facilitate sustainable development. Ruhanen discusses this in the context of general tourism development but if the regional tourism economy is viewed from a heterodox viewpoint (i.e. being made up of multiple, co-evolving tourism paths), the power of local government is even more pronounced as it undoubtedly favours some paths over others. This important distinction relates closely to Viken and Aarsaether's (2013) observations that the relationships between stakeholders are vital elements of tourism development and that, although networks normally have the benefit of empowering their members, they can also become closed structures from which certain stakeholders are excluded, a fact which can hinder the pursuit of sustainable tourism development.

It is well established that tourism networks are important for knowledge transfer and innovation (e.g. Weidenfeld, Williams, \& Butler, 2010) with Bramwell and Meyer (2007) going as far as to say it is the interaction itself which gives economic entities 
their meaning. It behoves the tourism academy, then, to closely examine the diversity among regional stakeholders and the power relations between them (Dredge, 2006; Reed, 1997; Viken \& Aarsaether, 2013) in order to better understand the long-term development potential of all regional tourism paths. This is often forgotten in regions combining one or a few marquee attractions with other, more rural offers (cf. Kauppila et al., 2009). It is also important to note that these networks are not closed off to tourism but are often integrated or entangled with other local development initiatives (cf. George, Mair, \& Reid, 2009; Haugland, 2011).

This paper posits that there are multiple, co-evolving paths and begs the question of which micro-processes are driving the evolution of these paths. Brouder and Eriksson (2013b) found that related and local experience helped new tourism firms stay in business and contribute to tourism development in a region not traditionally associated with tourism entrepreneurship. Also, a growing number of lifestyle entrepreneurs in the tourism sector are not primarily interested in the achievement of economic goals, such as profit-making or job creation, but are most concerned about making a living and enjoying a good quality of life as their businesses evolve over time (e.g. Andersson Cederholdm \& Hultman, 2010; Atlejevic \& Doorne, 2000; Marchant \& Mottiar, 2011). In broader terms, Thomas, Shaw, and Page (2011) call for further studies on the contribution of tourism entrepreneurs to long-term regional development. Since tourism is dominated by small enterprises, it is entirely reasonable to look across all the sub-sectors in any given region for evidence of positive long-term change (cf. Müller \& Brouder, 2014).

A better awareness of what is out there at the grass-roots level will lead to a broader understanding of ongoing developments and the potential for multiple paths to coevolve and complement each other going forward. Finally, it is important to note that not all definitions of development in this literature section are in line with the concept of CED. However, this paper shows that evolutionary approaches to studies of the tourism economy are open to broader conceptualisations of development than monetary, growth-oriented definitions allow.

\section{Method}

The paper uses semi-structured, in-depth interviews with regional tourism stakeholders to investigate new perspectives on tourism in the Niagara region. Qualitative fieldwork was conducted in the summer of 2013. Respondents were purposively chosen (Valentine, 2005) to include a range of different types of tourism planners in the region. Six interviews were conducted. Though the number of interviews was relatively low, the multiple roles of interviewees and the geographic networks they are a part of in the region mean that almost all of the rural parts of the Niagara region were represented. Interviews were conducted by both authors with one taking the lead and the other interjecting as and when appropriate. This created an effective discursive environment between the interviewees and the interviewers. Given the exploratory nature of the study and the small size of the region under study, the number of respondents was appropriate and saturation was being reached by the fifth and sixth interviews. The interview study was augmented by participant observation of the Niagara Tourism Network (an independent group which meets once a month to share information and 
primarily consists of stakeholders from the more peripheral areas of the Niagara region).

Thematic analysis was employed in the post-interview stage (Quinn Patton, 2002). The interviews were analysed in line with the five research questions listed earlier. An iterative process between the researchers, through discussion of and reflection on the materials and the extant literature, facilitated a robust and critical analysis with each author analysing the material independently first and then comparing emerging themes later. Only the results which were strongly evidenced in the material and which were highly relevant to the overall aim were included. One clarification is that the definition of tourism as CED presented above may not have been precisely consistent with how some of the interviewees see tourism development. Interviewees who diverged from the stated definition in this paper did so towards a "boosterist" version, reflecting the persistent and unrealistic expectations of tourism growth which some stakeholders maintain.

\section{Results}

\section{Path Dependence}

The path dependence of the Niagara region comes from its long history as part of the industrial heartland of North America and its traditional role as an agricultural region. As the restructuring processes discussed earlier unfolded, Niagara's municipalities were forced to diversify their economies, with most having identified tourism development as one possible hope for the future. As one interviewee noted, the economic hardships caused by regional restructuring "forced us to get into all of the games" (Interviewee \#4). Fortunately for most of these communities, the region's industrial and agricultural legacies have provided many of the place-based assets needed for tourism development. For example, the Welland Canal was built to enable ships to bypass the Niagara River while en route between Lakes Erie and Ontario. This waterway has been rerouted numerous times, and one of the now-closed-off sections, in Welland, serves as a flatwater-rowing venue and hosts numerous national and international events and competitions. The Welland Canal also provides the backdrop to Port Colborne's Canal Days Marine Heritage Festival. Nevertheless, one interviewee noted that the "tourism industry has under-valued the Welland Canal" (Interviewee \#6), and that there were many more ways in which the Canal could be harnessed for tourism development.

Despite the availability of marketable tourism assets, a major challenge for peripheral parts of the region has been to convince that ever-present group of Niagara Falls visitors to "come for the Falls but stay longer ... and spread out" (Interviewee \#1). Given the iconicity of the Falls, and with over a century of tourism development in the vicinity, the Niagara region's tourism economy has traditionally centred on the Niagara Falls area. This has created a situation where "people think Niagara is the Falls and that's it ... it's so ingrained" (Interviewee \#1). According to some interviewees, overcoming this challenge has been made more difficult by the fact that regional government officials have not given adequate attention to tourism development in peripheral parts of Niagara. Instead, they argued, tourism is not seen as a possible solution to economic 
woes with regional economic development practitioners said to be "still hung up on industry" (Interviewee \#1). This has meant that grass-roots development of tourism has not received much encouragement over the years. At the same time, while this has arguably stunted growth, it may also mean that the growth being witnessed today is more resilient than in comparable regions where tourism is driven by a "boosterist" planning arm.

Attempts at breaking from path dependence are notoriously difficult. This is no different in the Niagara region, where there has sometimes been a lack of capacity to act on the new opportunities which tourism presents. In the interviews, several peripheral stakeholders admitted their communities and businesses had little presence in the regional tourism promotional material "because we haven't got our act together" (Interviewee \#1), and that the peripheral parts of the Niagara region suffered from a "lack of cohesive identity and purpose" (Interviewee \#4). Many also noted that it was up to their groups themselves to become more assertive and proactive in building recognition of their tourism offerings; for example, one participant noted that "we need to set the message here, too" (Interviewee \#5). Furthermore, according to the interviewees, the residents and business owners in some places did not see their communities as a tourism destination (e.g. Wainfleet is about agriculture first and foremost, while Grimsby is seen as an industrial town or as a commuter community), which makes it more difficult to achieve local buy-in and support for tourism development.

All interviewees acknowledged the value of having an iconic attraction in the region - Niagara Falls. As one commented, having "major attractions in the region is a huge advantage" (Interviewee \#3). Another drew comparisons to Napa, California, in saying that "maybe the Falls is our Napa City" (Interviewee \#2), implying that the region can benefit from the cascade effect of visitors spreading out from the central attraction in the region. However, several interviewees acknowledged the presence of the Falls as somewhat of a "double-edged sword", given that many people identify Niagara Falls and the Niagara region as being one and the same thing. However, the more central places cannot easily escape their own tourism path dependence either. Some stakeholders were critical of what they saw as a myopic view on the part of the TPN, whereby "they understand their world, [but] have no clue what tourism is here" (Interviewee \#5). Another interviewee went so far as to state the TPN was "doing a disservice to the partners" by not actively engaging all of them in their marketing activities (Interviewee \#6). This path-dependent legacy is reflected in the make-up of the TPN, which has "only one board member south of Highway 20" (the midway line between the north and south of the Niagara region) (Interviewee \#3). This geographically biased constellation may have made much more sense in the past, when tourism was a less important part of all Niagara municipalities' economies. However, as tourism continues to grow across the region, it has become a barrier to intra-regional understanding and cooperation among stakeholders.

\section{Long-term Processes of Change}

In order to understand the long-term processes of change within tourism in the Niagara region, it is important to delve into the network relations which exist therein. In general, network relations occur in "a loose way" (Interviewee \#1) among the peripheral 
regional stakeholders. Several stakeholders, however, have formal administrative roles in municipal authorities, and these stakeholders are central in driving new tourism development. The recent establishment of the Niagara's South Coast Tourism Association (NSCTA) is a good example of this. The NSCTA's director is the only board member who is not an entrepreneur, but he has been an essential member because "someone needed to get it going ... get the ball rolling" (Interviewee \#3), even if the association itself "needs to be business driven" (Interviewee \#3). Thus, the inaugural board of directors sees its role as building the capacity of the association first; then, once entrepreneurs accept the association, the next step is to engage in relationshipbuilding. The director of the NSCTA also built another important network relationship by consulting with other Niagara-based tourism organisations in order to learn from their experiences. This, he said, allowed the NSCTA to "hit the ground running" (Interviewee \#3).

The rationale behind the new association (as with other local tourism associations across the region) is threefold: (1) it creates a "destination beyond municipal boundaries" (Interviewee \#3) so that tourists perceive the locale as a place to visit with many activities to offer; (2) it strengthens their ability to communicate with and leverage resources from the TPN: "the South Coast Tourism Association is stronger; individually we're not even at the table" (Interviewee \#5) and (3) it creates the local communication and knowledge exchange channel which was missing in the past. As one interviewee noted about two businesses that are now promoting one another to their clients: "they are only twenty minutes apart but they're - if you go back ten years - somehow two municipalities apart. Those relationships are starting to form" (Interviewee \#3). This final point was also reinforced by a member of a more established tourism association where the creation of that network "has driven a lot of us together" (Interviewee \#2). In fact, in the more mature association "exhibitors as well as tourists want to be part [of the association and its organised events] due to the buzz" (Interviewee \#2). Thus, the local networks themselves allow positive processes to form and become embedded locally and this intra-regional, continuous interaction leads to noticeable tourism development over time.

Many of the interviewees also identified further prospects for local and regional tourism development that had not yet been fully, or even formally, pursued. In several cases, these opportunities involved tapping into the creative economy by integrating the arts and culture into the tourism economy - that is, by "blending culture with tourism" (Interviewee \#2). Some of the communities have already begun this process, primarily by organising events aimed at both local residents and out-oftown visitors, such as food festivals and concerts at wineries. These have often involved the participation of entrepreneurs from multiple communities at individual events. For example, several wineries from the northern part of Niagara routinely participate in the food festivals in Welland and Port Colborne, both of which are beyond "Wine Country" in the southern part of the region. Some communities have great potential for further growth by merging tourism and the creative arts since the population of artisans and other cultural entrepreneurs has been growing tremendously (e.g. one interviewee reported the presence of many more studios and collectives than they had ten years ago, with about three-quarters of these home-grown (Interviewee \#3)). Others, however, noted that their municipalities were far behind in terms of harnessing the 
arts and culture sector for tourism development purposes, a typical statement being: "we have a lot of creativity but we haven't made those connections [to tourism] yet" (Interviewee \#5).

Finally, the interviews revealed a desire and willingness of all the represented communities to work with at least some of their regional neighbours to promote tourism development. For example, the Twenty Valley Tourism Association has grown beyond its original boundaries within the town of Lincoln to now include several members from the city of St. Catharines, located to its immediate east; it is also attempting to entice members from the town of Grimsby, located on Lincoln's western flank. At the same time, the creation of the NSCTA represents another important step in Niagara's regional tourism development, given that it has involved the cooperation of five separate municipalities.

There is thus a good chance that, collectively, tourism will play a key role in the economic revitalisation of the many small towns of Niagara that have suffered from decline in the agricultural and industrial sectors over the past several decades. As one interview participant noted, "We all have assets, [but] people haven't spent enough time figuring out where they are, what they are, and what niche goes with it" (Interviewee \#6). Indeed, the cooperation, enthusiasm and general "buzz" that stem from communities and entrepreneurs networking and collaborating have great potential to assist in turning the economic tide, not only on Niagara's south coast, but also on its north coast and within the urban and rural areas in between. However, the question of whether this will include - and, if so, to what extent - the dominant regional tourism player, Niagara Falls, remains to be seen. Although much could be gained if Niagara Falls and the more peripheral parts of Niagara came together more formally to promote tourism development throughout the region, it may take several more years of sub-regional tourism organisation growth and intra-regional networking (including politicians, planners and businesses) for this to happen.

\section{Discussion and Conclusion}

There are two elements to path dependence in tourism development in Niagara - the general and traditional dependence on manufacturing as the driver of economic growth (cf. Kauppila et al., 2009) and the particular and ingrained emphasis on the Falls region as the focal point of tourism activities. This has led to a local blindness to the positive tourism developments across the region as well as a persistent belief that tourism benefits will cascade from the Niagara Falls area to other parts of the region. The organic, endogenous changes which are slowly developing across the region are challenging these perceptions and leading to a new understanding of tourism development in the Niagara region - one based on the co-evolution of several paths.

\section{Co-evolving Paths}

There are numerous co-evolving paths of tourism development across the Niagara region. These can be seen at both the micro-level (between individual entrepreneurs and planners in a given locale) and at the meso-level (between planners operating 
across local boundaries) (cf. Haugland, 2011). Due to the nature of tourism development in a relatively small region such as Niagara, the web of relations between tourism stakeholders is quite complicated and tangled (cf. Dredge, 2006). Entrepreneurs also frequently have roles on local or regional tourism associations, while, at the same time, municipal planners may have roles that extend beyond their own municipality. For example, all interviewees who took part in this research were working within the realm of tourism planning, but in many cases this was not their only (or even their main) role.

Moreover, the pool of tourism stakeholders in the region is not particularly large, so interviewees knew each other quite well in most cases and had worked with each other both formally and informally, for both tourism and other local developments, over the years. In this sense, unpacking the various tourism development paths will necessarily show some form of co-evolution. However, there is evidence of co-evolution beyond simple association. For example, the desire to develop tourism which supports local artists and leads to a better quality of life for residents as well as tourists is an example of sustainable tourism which is in line with community development goals (Andersson Cederholdm \& Hultman, 2010; Ateljevic \& Doorne, 2000; Brouder, 2012; Fullerton, 2010; George et al., 2009).

The co-evolving paths also show the intra-regional diversity of the Niagara region. First, the physical geography of the region has allowed the evolution of the wine sector in distinct sub-regions. Certain places along the Niagara Escarpment are suitable for growing wine grapes, and yet they have developed at different times. Niagara-onthe-Lake is long-established and has helped to create Niagara's reputation as a wine region. However, the more recent explosion of wineries in the Twenty Valley area is due to its having the right physical conditions but is also due to the earlier success of Niagara-on-the-Lake wineries in building a market for Niagara wines. This has likely helped Twenty Valley's wine tourism industry to blossom quickly. This also shows that tourism development is complex (Milne \& Ateljevic, 2001) and evolving continuously over time (Brouder \& Eriksson, 2013a), even in relatively small regions.

There are meaningful changes to network relations occurring in the Niagara region, including horizontal and vertical as well as formal and informal. As noted earlier, it is difficult to unpack specific actors' influences on those changes since actors often have multiple roles within the region, but the changes, once embedded, become self-reinforcing over time (cf. Brouder, 2013). For example, the Twenty Valley Tourism Association has a strong voice in the TPN and figures prominently in the latest edition of the Niagara Canada Travel magazine (Niagara Travel, 2013). This is undoubtedly a result of the association working horizontally to develop its market offer as well as vertically to leverage the significant market power of the TPN (e.g. the Niagara Canada Travel magazine has a circulation of 775,000$)$. Twenty Valley had to work hard to get to this point - by developing a critical mass of local tourism products as well as developing a relationship with the TPN, each of which has taken a long time - but by comparing the situation today with that of a decade ago, it is clear that a marked change has occurred.

What is also clear is that there is potential for mutual benefit if greater links and cooperation could be built up across the entire region. An increase in tourism product across the region was seen as something that could compensate for what has 
become a stagnant Niagara Falls tourism industry in recent years. Thus, Niagara Falls could benefit from grounding itself more firmly in the region which bears its name, while the region's more peripheral tourism attractions could prosper from tapping into the incredibly large Niagara Falls tourism market. Such development must be seen as a number of co-evolving local tourism development paths, even if not all paths are equal in stature or scope. By understanding the co-evolution of the iconic attraction at the centre and the developing attractions across the region, there is an increased likelihood of tourism development which is sustainable and which addresses the needs of the communities (Fullerton, 2010; Ma \& Hassink, 2013; Viken \& Aarsaether, 2013).

The future is dependent, to a large extent, on the past. While change comes slowly, it needs to be understood as a complex process evolving over time (Brouder \& Eriksson, 2013a; Milne \& Ateljevic, 2001). The current and ongoing changes across the Niagara region are organic and mostly endogenous. Large strides have been made and are noticeable in comparison with previous decades and there remains greater potential in the coming decades. The development of tourism in the Niagara region will only be sustainable if it is understood, not as a traditional cascade effect from Niagara Falls to the more peripheral communities, but as a co-evolving, community-driven endeavour.

\section{Acknowledgement}

Patrick Brouder is a Banting Postdoctoral Fellow and Christopher Fullerton is an Associate Professor at the Department of Geography, Brock University. This work was supported by a grant from Brock University's Council for Research in the Social Sciences.

\section{Disclosure statement}

No potential conflict of interest was reported by the author(s).

\section{References}

Andersson Cederholm, E., \& Hultman, J. (2010). The value of intimacy - negotiating commercial relationships in lifestyle entrepreneurship. Scandinavian Journal of Hospitality and Tourism, 10(1), 16-32. doi: $10.1080 / 15022250903442096$

Ateljevic, I., \& Doorne, S. (2000). "Staying within the fence": Lifestyle entrepreneurship in tourism. Journal of Sustainable Tourism, 8(5), 378-392. doi:10.1080/09669580008667374

Boschma, R., \& Martin, R. (2010). The handbook of evolutionary economic geography. Cheltenham: Edward Elgar.

Bramwell, B., \& Meyer, D. (2007). Power and tourism policy relations in transition. Annals of Tourism Research, 34(3), 766-788. doi:10.1016/j.annals.2007.03.009

Brooker, E., \& Burgess, J. (2008). Marketing destination Niagara effectively through the tourism life cycle. International Journal of Contemporary Hospitality Management, 20(3), 278-292. doi:10.1108/ 09596110810866091

Brouder, P. (2012). Creative outposts: Tourism's place in rural innovation. Tourism Planning \& Development, 9(4), 383-396. doi:10.1080/21568316.2012.726254 
Brouder, P. (2013). Embedding Arctic tourism innovation in "creative outposts". In R. H. Lemelin, P. Maher, \& D. Liggett (Eds.), From talk to action: How tourism is changing the polar regions (pp. 183-198). Thunder Bay, ON: Centre for Northern Studies Press.

Brouder, P. (2014a). Evolutionary economic geography: A new path for tourism studies? Tourism Geographies, 16(1), 2-7. doi:10.1080/14616688.2013.864323

Brouder, P. (2014b). Evolutionary economic geography and tourism studies: Extant studies and future research directions. Tourism Geographies, 16(4), 540-545. doi:10.1080/14616688.2014.947314

Brouder, P., \& Eriksson, R. H. (2013a). Tourism evolution: On the synergies of tourism studies and evolutionary economic geography. Annals of Tourism Research, 43, 370-389. doi:10.1016/j.annals.2013. 07.001

Brouder, P., \& Eriksson, R. H. (2013b). Staying power: What influences micro-firm survival in tourism? Tourism Geographies, 15(1), 125-144. doi:10.1080/14616688.2011.647326

Carmichael, B. (2005). Understanding the wine tourism experience for winery visitors in the Niagara Region, Ontario, Canada. Tourism Geographies, 7(2), 185-204. doi:10.1080/14616680500072414

Cohen, E. (1979). Rethinking the sociology of tourism. Annals of Tourism Research, 6(1), 18-35. doi:10. 1016/0160-7383(79)90092-6

Deloitte \& Touche. (2008). Making it happen: Shaping Niagara and other Canadian regional tourism for tomorrow. Toronto: Deloitte and Touche LLP.

Dredge, D. (2006). Networks, conflict and collaborative communities. Journal of Sustainable Tourism, 14(6), 562-581. doi:10.2167/jost567.0

Dubinsky, K. (1999). The second greatest disappointment: Honeymooning and tourism at Niagara Falls. Toronto: Between the Lines.

Eaton, E. (2004, March). Agri-tourism and sustainability in Niagara. Paper presented at Leading Edge 2004: The Working Biosphere, St. Catharines, ON.

Fullerton, C. (2010). Exploring the potential contributions of community economic development to rural revitalization. In D. Winchell, D. Ramsey, R. Koster, \& G. Robinson (Eds.), Geographical perspectives on sustainable rural community change (pp. 426-446). Brandon, MB: Rural Development Institute.

Fullerton, C. (2013). The growing place of wine in the economic development of the Niagara region. In M. Ripmeester, P. G. Mackintosh, \& C. Fullerton (Eds.), The world of Niagara wine (pp. 47-63). Waterloo, ON: Wilfrid Laurier University Press.

Gayler, H. (2010). Niagara's emerging wine culture: From a countryside of production to consumption. In J. Nicks \& N. Baxter-Moore (Eds.), Covering Niagara: Studies in local popular culture (pp. 195-212). Waterloo, ON: Wilfrid Laurier University Press.

George, E. W., Mair, H., \& Reid, D. G. (2009). Rural tourism development: Localism and cultural change. North York, ON: Channel View.

Haugland, S. (2011). Development of tourism destinations: An integrated multilevel perspective. Annals of Tourism Research, 38(1), 268-290. doi:10.1016/j.annals.2010.08.008

Hickey, R. (2008). Challenges and opportunities for improving employment conditions in Niagara's hotel sector (UNITE HERE Canada Report). Retrieved May 31, 2014, from OPSEU 217: http://www. opseu217.com/mambo/images/stories/pdf/unite_here_report_on_niagara_hotel_sector.pdf

Jayawardena, C., Patterson, D. J., Choi, C., \& Brain, R. (2008). Sustainable tourism development in Niagara: Discussions, theories, projects and insights. International Journal of Contemporary Hospitality Management, 20(3), 258-277. doi:10.1108/09596110810866082

Karlsson, S. E. (2005). The social and the cultural capital of a place and their influence on the production of tourism - a theoretical reflection based on an illustrative case study. Scandinavian Journal of Hospitality and Tourism, 5(2), 102-115. doi:10.1080/15022250510014408

Kauppila, P., Saarinen, J., \& Leinonen, R. (2009). Sustainable tourism planning and regional development in peripheries: A Nordic view. Scandinavian Journal of Hospitality and Tourism, 9(4), 424-435. doi:10.1080/15022250903175274

Larsson, A., \& Lindström, K. (2013). Bridging the knowledge-gap between the old and the new: Regional marine experience production in Orust, Västra Götaland, Sweden. European Planning Studies, 22(8), 1551-1568. doi:10.1080/09654313.2013.784578

Ma, M., \& Hassink, R. (2013). An evolutionary perspective on tourism area development. Annals of Tourism Research, 41, 89-109. doi:10.1016/j.annals.2012.12.004 
MacLaurin, D. J., \& Wolstenholme, S. (2008). An analysis of the gaming industry in the Niagara region. International Journal of Contemporary Hospitality Management, 20(3), 320-331. doi:10.1108/ 09596110810866136

Mah, A. (2012). Industrial ruination, community, and place: Landscapes and legacies of urban decline. Toronto: University of Toronto Press.

Marchant, B., \& Mottiar, Z. (2011). Understanding lifestyle entrepreneurs and digging beneath the issue of profits: Profiling surf tourism lifestyle entrepreneurs in Ireland. Tourism Planning \& Development, 8(2), 171-183. doi:10.1080/21568316.2011.573917

Martin, R. (2010). Roepke lecture in economic geography—rethinking regional path dependence: Beyond lock-in to evolution. Economic Geography, 86(1), 1-27. doi:10.1111/j.1944-8287.2009.01056.x

Milne, S., \& Ateljevic, I. (2001). Tourism, economic development and the global-local nexus: Theory embracing complexity. Tourism Geographies, 3(4), 369-393. doi:10.1080/146166800110070478

Mitchell, C., Atkinson, G., \& Clark, A. (2001). The creative destruction of Niagara-on-the-Lake. The Canadian Geographer, 45(2), 285-299. doi:10.1111/j.1541-0064.2001.tb01489.x

Müller, D. K., \& Brouder, P. (2014). Dynamic development or destined to decline? the case of Arctic tourism businesses and local labour markets in Jokkmokk, Sweden. In A. Viken, \& B. Granås (Eds.), Tourism destination development: Turns and tactics (pp. 227-244). Farnham: Ashgate.

Neffke, F., \& Svensson Henning, M. (2010). Seeds of structural change. The role of entrepreneurs and expanding firms in shaping local path dependencies. Rotterdam: Erasmus Research Institute of Management.

Niagara Region. (2012). Niagara population 1996-2011. Retrieved May 31, 2014, from: https://www. niagararegion.ca/about-niagara/statistics/population-and-maps.aspx

Niagara Travel. (2013). Travel magazine of the tourism partnership of Niagara. Retrieved May 31, 2014, from: http://visitniagaracanada.com/magazines/niagara-travel-2013

Ontario Tourism Competitiveness Study. (2009). Discovering Ontario: A report on the future of Ontario tourism. Toronto: Queen's Printer for Ontario.

Papatheodorou, A. (2004). Exploring the evolution of tourism resorts. Annals of Tourism Research, 31(1), 219-237. doi:10.1016/j.annals.2003.10.004

Quinn Patton, M. (2002). Qualitative research and evaluation methods. London: Sage.

Reed, M. (1997). Power relations and community-based tourism planning. Annals of Tourism Research, 24(3), 566-591. doi:10.1016/S0160-7383(97)00023-6

Reijonen, J. (2008). Understanding the small business owner: What they really aim at and how this relates to firm performance: A case study in North Karelia, Eastern Finland. Management Research News, 31(8), 616-629. doi:10.1108/01409170810892172

Ripmeester, M., Mackintosh, P. G., \& Fullerton, C. (2013). The world of Niagara wine. Waterloo: Wilfrid Laurier University Press.

Ruhanen, L. (2013). Local government: Facilitator or inhibitor of sustainable tourism development? Journal of Sustainable Tourism, 21(1), 80-98. doi:10.1080/09669582.2012.680463

Telfer, D. (2001). Strategic alliances along the Niagara Wine Route. Tourism Management, 22(1), 21-30. doi:10.1016/S0261-5177(00)00033-9

Telfer, D., \& Hashimoto, A. (2013). Wine and culinary tourism in Niagara. In M. Ripmeester, P. G. Mackintosh, \& C. Fullerton (Eds.), The world of Niagara wine (pp. 281-299). Waterloo: Wilfrid Laurier University Press.

Thomas, R., Shaw, G., \& Page, S. J. (2011). Understanding small firms in tourism: A perspective on research trends and challenges. Tourism Management, 32(5), 963-976. doi:10.1016/j.tourman. 2011.02.003

Valentine, G. (2005). Tell me about ... using interviews as a research methodology. In R. Flowerdew \& D. Martin (Eds.), Methods in human geography: A guide for students doing a research project (pp. $110-127)$. Harlow: Pearson.

Viken, A., \& Aarsaether, N. (2013). Transforming an iconic attraction into a diversified destination: The case of North Cape tourism. Scandinavian Journal of Hospitality and Tourism, 13(1), 38-54. doi:10.1080/15022250.2013.771994

Weidenfeld, A., Williams, A. M., \& Butler, R. W. (2010). Knowledge transfer and innovation among attractions. Annals of Tourism Research, 37(3), 604-626. doi:10.1016/j.annals.2009.12.001 